Journal of Awareness

Cilt / Volume 5, Say1 / Issue 3, 2020, pp. 257-268

E - ISSN: 2149-6544

URL: https://journals.gen.tr/joa

DOİ: https://doi.org/10.26809/joa.5.019

Araştırma Makalesi / Research Article

\title{
WHAT FACTORS PREVENT INDEPENDENT DIRECTORS FROM PROTECTING INTERESTS OF SHAREHOLDERS IN CASES OF CONFLICT OF INTEREST?
}

\author{
Murad JAFARLI* \\ * Master of Laws, Vytautas Magnus University, \\ LITHUANIA, e-mail: mr.murad.jafarli@gmail.com \\ ORCID: https://orcid.org/0000-0002-5493-6846
}

Received: 17 March 2020; Accepted: 16 July 2020

\begin{abstract}
One way to mitigate agency conflicts between shareholders and managers in publicly traded companies with dispersed ownership is supplementation of independent outside directors to the board, who can monitor the top executives and prevent them from malfeasances. However, in conflict of interest situations, independent board members are not always enabled to oppose senior managers, particularly CEOs, who put their personal interests above those of shareholders. In such cases, the efforts of independent directors to monitor managers will be unsuccessful, which, in turn, may result in the latter receiving unjustified personal benefits at the expense of shareholders. Active participation of independent directors in resolving situations where interests of these groups do not align ensures the mitigation of tension and the proper functioning of the company. Thus, the establishment of cases where independent outsiders cannot fulfill their basic duties of shielding shareholders appears to be rather a significant issue.
\end{abstract}

Keywords: Independent directors, CEO, Shareholders, Conflict of interest. 


\section{INTRODUCTION}

The majority of modern publicly held companies are characterized by the separation of ownership and control. As a rule, shareholders of large listed companies, who are dispersed, frequently face difficulties in coordination and collective actions, consequently, they possess little or no direct control over top management decisions. If one considers corporate governance from the point of view of agency theory (Kraakman et al, 2016), it becomes clear that such a separation can lead to the formation of a rather large gap between the principals (shareholders) and agents (managers) of the company. In such circumstances, the importance of the board of directors increases significantly, since control over the activities of managers and protection of the interests of shareholders rests on the shoulders of board members.

However, what parameters determine an effective board of directors? The issue of the composition of the board of directors for many years has been and remains one of the most pressing in corporate law. In the whole corporate system, strong boards of directors are considered as a pivotal mechanism for mitigating the shareholder-management agency problem, which can protect the interests of company shareholders. Currently, the boards of companies, in particular, those that are publicly traded and large, come into the limelight of the corporate governance debates. Contemporary corporate governance standards define the independence of directors as one of the main indicators of the effectiveness of the board of directors. In this context, independent outside directors are deemed to be a solution to potential conflicts between shareholders and management in listed companies. Nowadays, the presence of independent directors on the board of public companies is generally accepted and widely used practice in the majority of jurisdictions, especially in those with the dispersed ownership structure. ${ }^{1}$

Nevertheless, the mere presence of independent directors on the board of directors is not a panacea, since it does not guarantee the elimination of management-shareholder conflicts and the enhancement of corporate governance in all cases. In general, many factors affect the performance of the obligations of the independent directors. Independent outsiders face plenty of obstacles in the course of the execution of their obligations. Sometimes independent directors are not aware of the majority of scrupulous conflicts of interest that they are engaged in. The board is a specific place where the egos of different groups constantly clash and there is a struggle for authority and influence. It is hard to understand, in this clutter, how and where the outsiders may acquire reliable information to eliminate information asymmetry and act in the best interest of shareholders.

Such complications raise the question: Do independent directors act as advocates for shareholder-minded management in cases of conflict of interest? It is obvious that the lack of balance in relations with insiders and managers, partially or completely limited access to information, incentive issues as well as dependence on senior management, to various degrees, impede them from improving corporate governance and creating shareholder value.

Scientific problem of this study is that independent outside directors included in the boards of publicly held companies face various factors preventing them from protecting the best interests of shareholders through monitoring and advising senior management.

Aim of the research is to identify all obstacles that prevent independent directors from protecting the interests of shareholders in conflict-of-interest cases.

Object of the work is conflict of interest situations between shareholders and top management of publicly held companies.

The research method of the study is doctrinal and desk-based research based on a review and synthesis of published literature. The methodological framework of this research is 
a comprehensive analysis of the results of fundamental and applied research in the field of corporate governance, the composition of the board of directors and the role of independent directors in it. The present research is based on both general research methods, such as comparative and qualitative, and special methods of scientific research, including abstractlogical, analysis and synthesis, as well as logical and analytical generalizations. All sources used are publicly available.

\section{CEO DISMISSAL AND APPOINTMENT}

Monitoring of the performance of the top executives by the board of directors manifests itself in the two significant decisions: deposition of inefficient managers and hiring of new management that will run the company in a shareholder-oriented manner. Shareholders can reasonably expect timely and adequate intervention of the board in inappropriate management decisions only if the directors sitting on the board are truly independent.

\subsection{Factors complicating the dismissal of CEOs}

As Bebchuk and Fried (2004) emphasize, an effective corporate governance model suggests that in the event of poor company performance, the board of directors will replace the CEO with a more competent person. Dismissal of the CEO is one of the most important and most responsible decisions made by the board since it greatly affects the vector of development of the firm. However, its implementation is fraught with a number of hurdles for the boards. In particular, entrenched CEOs often have enough power and influence over the board to maintain their position even if the company's performance is rather poor. ${ }^{2}$

The composition of the board considered an important parameter of the sensitivity of CEO turnover to the company performance. Weisbach (1988) suggests that the bigger the fraction of independent directors on the board of directors, the greater the possibility that a poorly performing CEO will be fired. Moreover, Masulis and Guo (2015) find that nominating committee independence leads to the greater sensitivity of forced CEO turnover to performance. The dismissal of the CEO in most cases is determined by the activities of independent outsiders, as other board members often turn a blind eye to the CEO's low level of efficacy. As a rule, inside directors rarely dare to oppose CEOs by reason of a career dependence on senior management. Grey directors who have existing or potential business connections with the company also prefer not to be involved in confrontations and spoil their relationship with the CEO, who determines the main directions of the company's business activities. In addition, CEO change often creates risk of dismissal for non-independent directors. For instance, in the year of CEO replacement, on average, 2.6 dependent directors leave their posts while 2.46 new dependent directors are hired. ${ }^{3}$

Besides, the optimal board structure is also determined by the total number of directors serving on the board. This factor is especially acute when making strategically significant decisions, such as the dismissal of the CEO. An overly large board of directors may also be seen as one of the barriers to the removal of inefficient CEOs. Excessively large boards are characterized by the complexity of organization and unity, as well as free-rider problem, which contribute to CEO entrenchment.

The position and entrenchment of CEOs are highly dependent on the length of their tenure. A long tenure in the position gives CEOs the opportunity to strengthen their bargaining power and gain more favorable conditions from the board. According to Graham et al. (2019), long tenure also increases the likelihood of CEOs becoming chairpersons, allowing them to increase their influence on board members. In particular, entrenched CEOs, over time, seek to reduce monitoring, which leads to them maintaining their positions even if the company's performance deteriorates. For example, the recent study (Dikolli et al. 2014) emphasizes that 
CEOs' turnover sensitivity to the company performance considerably weakens over their tenure. Accordingly, CEOs with unreasonably long tenures avoid dismissal due to a weak monitoring system, and not past successes at the head of the company. If the CEO manages to reduce the board independence, then weak monitoring is expected during the entire period in which this CEO is in office. This conclusion is consistent with Graham et al. (2017), that the structure of the boards remains constant, which determines the tendency of the board of directors to dismiss the CEO.

In general, in the initial periods of his stay in the company, a new CEO often faces intensive monitoring due to the uncertainty about his abilities. During such a period when CEOs have not yet entrenched and have not weakened monitoring, they are at risk of dismissal. Jenter and Lewellen (2015) illustrate that the likelihood of a forced turnover for CEOs is highest in the first two years of office. In subsequent years, as the uncertainty regarding the CEO's abilities is eliminated, the board becomes more lenient and its independence, as well as the degree of monitoring, gradually diminishes. Thus, with the increase in the tenure of the CEO, the probability of his dismissal decreases. In addition, it is necessary for the board of directors to learn information about the director's abilities as quickly as possible. Otherwise, the likelihood of holding the post by an ineffective CEO increases, which also does not align with the interests of the company and shareholders.

\subsection{Replacement of the dismissed CEO}

As a rule, the dismissal of an incompetent CEO is only the first step towards improving corporate governance. It is quite complicated and costly to find a worthy replacement for the dismissed CEO. The appointment of a new CEO cannot be random; the board should fill the vacancy based not only on the personal characteristics of the candidates but also on the principal peculiarities of the firm and its business line and investment strategy. A considerable role in the search and hiring of a new CEO are played by the conditions of the external labor market. As Hermalin (2005) notes, if the external labor market ensures sufficient access to potential management replacements, boards of directors will be more responsive to the weak company performance and more active in CEO dismissal.

When searching for a new CEO, the board may prefer an outsider invitation in lieu of insider promotion. Murphy and Zábojník (2007) show that the percentage of outside hires has been growing since the second half of the last century and in the early 2000s, and approximately a third of all CEOs hired were outsiders. The authors also find that boards of directors give preference to outsiders with prior CEO experience. This trend reflects the desire to hire highly qualified CEOs with a good reputation and experience in managing the company. In general, less-experienced CEOs are more likely to be fired than those with extensive managerial experience. ${ }^{4}$ Furthermore, after the dismissal of an inefficient CEO, the boards prefer to choose candidates who will run the company in a shareholder-oriented manner. If company insiders are considered as supporters and successors of the dismissed CEO, their appointment will have no amelioration effect for the firm. Consequently, the appointment of an insider to the post of CEO is most reasonable to expect with the voluntary CEO resignation, and not with a forced turnover.

However, the above does not mean that in all cases of CEO dismissal external hire is more beneficial than insider promotion. Talented insiders of large companies have sufficient firm-specific knowledge to make key management decisions. In addition, these insiders, holding outside directorships, may not only reduce leadership change costs but also increase CEO turnover sensitivity to firm performance. ${ }^{5}$ The presence of healthy inside competition, in addition to facilitating the dismissal of the poor performing CEO, gives the board the 
opportunity to use internal resources if there is a need for company-specific knowledge rather than general managerial experience.

\section{EXECUTIVE COMPENSATION}

The issue of shareholder protection by the board of directors also appears in determining compensation of top management. Compensation packages of $\mathrm{C}$-suite executives, in particular in large listed companies, increases from year to year ${ }^{6}$, which raises questions about the shareholders' interests shielding. Murphy and Zábojník (2007) suggest that high executive pay results from increasing demand for general managerial skills, which prompts the boards of directors to hire outsider-CEOs.

In general, executive compensation may be interpreted as a significant parameter for improving managerial incentives. However, not in all cases, excessively large CEO compensations are indicators of productive management. Entrenched CEOs, through their influence on the board, can achieve the establishment of unreasonably favorable conditions and extract rents at the expense of shareholders. Conventional wisdom holds that independent directors-dominated boards can achieve more frequent use of equity-based compensation, which contributes to the CEO's long-term interest in the development of the company. ${ }^{7}$ However, managers themselves prefer compensation in the form of cash, since cash payments are characterized by a much lower risk level. In comparison to shareholders, who can reduce their company-specific risk by diversifying their portfolios, managers invest their nondiversifiable and non-tradable human capital in the company. Accordingly, the level of the firmspecific risk for managers can differ significantly from those of shareholders.

In negotiations on hiring a new $\mathrm{CEO}$, it is difficult for the board of directors to decide on the amount of compensation that should be offered to the opposite party. CEOs' compensation bargaining power may greatly depend on their external labor market reputation. In other words, a successful management background is a trump card for CEOs during the negotiations on executive payment system. Prior career success, nonetheless, is not a guarantee of successful management.

Board's activity in monitoring the new CEO may affect compensation payments. Intensive monitoring of top executives decisions reflects a rather strict management dismissal policy of the company, which makes the proposal of the board of directors less attractive for candidates. In these cases of severe dismissal standards, the board is expected to propose high compensation packages to convince the desired candidate to hold the post of CEO. However, excessive lavish compensation, in particular severance payments, may ultimately undermine CEOs' incentive to operate properly ex-ante. Thereby, intensely monitoring independent boards are not catalysts for management effectiveness because CEOs know that in case of poor results and subsequent dismissal, they will still be paid large payments under the contract. Moreover, less competent CEOs who are not confident in their own abilities to successfully run the company and generate wealth, seek to receive the highest possible compensation packages due to the high degree of risk of losing their positions.

The determination of compensation may also be influenced by certain psychological or social factors. Directors understand that the candidate will soon occupy one of the leading positions in the company and may influence the compensation and term of office of these directors therefore, it is necessary to build respectful relationships with him. Relatively little time to search for a new CEO, as well as the aim to attract the desired candidate, encourages the board to conduct soft negotiations and agree to the terms of the opposite side.

As it is known, currently, many jurisdictions either recommend or require public companies to create a compensation committee, consisting mainly or entirely of independent 
directors. ${ }^{8}$ Independent directors of this committee are expected to favor equity-based compensation, i.e. more performance-sensitive payment system, to align management incentives with those of shareholders. Despite the fact that this compensation system seems a fairly effective way to interest the CEO in the shareholder value increasing, it may also increase the likelihood of excessive risk-taking or self-dealing transactions, including empire building. In other words, CEOs can promote and initiate extremely risky projects to increase their nondiversified human capital, which depends solely on the company's shares. The level of independence of the members of this committee has a significant impact on executive pay. As Main et al. (1995) note, the executive compensation rate increases when a director working on the compensation committee joins the board after the CEO takes the helm. As Sun and Cahan (2009) suggest, the formal independence of members is not a key parameter of compensation committee efficacy, and there are considerable quality differences among these independent compensation committees. Indeed, like the board of directors itself, the compensation committee may operate under the considerable influence of the CEO. In spite of the fact that at present CEOs are prohibited from sitting on the compensation committee, they are able to intervene in the activities of formally independent committee members in a variety of ways, such as combining the positions of the chairman and CEO. To prevent CEOs rent extraction, it is necessary to form committees with a proper level of quality and freedom from the influence of CEOs.

\section{M\&A TRANSACTIONS}

M\&A transactions are one of the most important and responsible investment decisions, which allow companies not only to grow and downsize quickly but also to alter the principal business direction and areas. Complexity, huge amounts of data and severe time constraints make these transactions extremely difficult for successful implementation. In addition, M\&A transactions can be another source of conflicts between shareholders and top management. If CEOs initiate or promote these projects guided by their personal goals and ambitions, then there can be no question of any increase in shareholder value. Hence, the active and independent board participation in mergers and acquisitions seems quite significant, given that these investment decisions have a substantial impact on shareholder welfare.

\subsection{Conflict-of-interest cases when the company is the acquiring side}

Basically, mergers and acquisitions rarely end up with abnormal shareholder return and, moreover, sometimes they can lead to serious destruction of shareholder value. For example, according to Moeller et al. (2005), in the period from 1998 to 2001, the loss of acquiringcompany shareholders amounted to $\$ 397$ billion, which equals to $\$ 2.31$ per dollar spent on the acquisition. Failed mergers and acquisitions may result from various factors. The level of knowledge and experience of an acquiring firm CEO affects the choice of the right target. In most cases, CEOs do not make M\&A decisions often, consequently, they lack the necessary skills and experience (Bao and Edmans, 2011). Shareholder value-destroying transactions may also be a consequence of excessive management confidence. Excessive and unreasonable belief in personal skills and capabilities of the company, as well as ignoring advice, can be determinant factors of CEO overconfidence. Malmendier and Tate (2008) posit that firms with overconfident CEOs are more likely to overpay, to be involved in value-destroying acquisitions, and to initiate acquisitions when they have ample internal resources. Overconfidence should not be confused with empire-building, which is another possible reason of unsuccessful and value-destroying M\&A decisions. The activities of an overconfident CEO aimed at making a profit and are characterized by an incorrect and erroneous assessment of the personal abilities to generate returns. In the case of empire-building, CEOs pursue purely personal aims and ambitions, marginalizing the interests of shareholders. 


\subsection{Conflict-of-interest cases when the company is the target of acquisition}

Protecting the interests of shareholders is also required in cases where the company is the target of acquisition. CEOs pursuing their personal benefits may agree to acquisitions or mergers that do not facilitate shareholder well-being. The management of the acquired company has two main sources of personal rent extraction. First, payments from the company itself, for instance, lump-sums cash payments or increases in pre-established golden parachutes. Hartzell et al. (2004) report that CEOs receive special cash payments from the board of directors in $27 \%$ of merger transactions, while in $12 \%$ of cases the board increases the value of the CEOs' golden parachute after the merger is approved. The authors calculated that after these decisions, on average, CEOs received additional income equal to $\$ 4.42$ and $\$ 3.25$ million, respectively. However, such payments appear reasonable, given that the board can thus express gratitude to the upper executive who contributed to the successful completion of the deal. In other words, it is more preferable for the board not to enter into a confrontation with the CEO and for successful completion of the shareholder-oriented transaction to include additional generous payments to the director, who will be displaced soon. Moreover, due to the fact that the directors do not incur personal losses from such decisions, the board of directors has no significant incentive to reject these sweetener payments.

The second source of personal benefits for directors in M\&A operations is the opposite side of the deal i.e. the acquiring company. A fairly common practice is when the acquiring company pays special compensation to the target firm's top management team (Sorkin, 2002). The logic of this is rather simple: by paying such compensation, the buyer not only speeds up the decision-making process but also contributes to the completion of the transaction on more advantageous conditions. Such a situation inevitably creates a threat of shareholder value destruction. A CEO will be seriously tempted if the opposing party offers generous payments for approving the operation, which, eventually, damages shareholders. In the end, such a CEO can, through his influence on the board, contribute to the implementation of the transaction, receive his payment and leave the company. Besides, even if a change of ownership promises to be extremely beneficial to shareholders, an entrenched CEO can simply resist lucrative M\&A proposals until he receives personal benefits. From a management point of view, mergers and acquisitions are not mutually beneficial transactions that influence the wealth of management and shareholders in different ways. The completion of a potentially successful M\&A transaction gives shareholders an opportunity to receive financial benefits, while for top management this is a risk of losing their permanent job. For this reason, top managers can have a strong incentive to use all means and obtain as much personal profit as possible. For example, a well-known M\&A lawyer in an interview with the New York Times said: "I have had a number of situations where we've gone to management looking to do a deal and been stopped at the door until a compensation arrangement was signed, sealed and delivered." Another merger lawyer described the situation as follows: "Publicly, we have to call these things retention bonuses. Privately, sometimes it's the only way we would have got the deal done. It's a kickback. And sometimes it's my job to negotiate the kickback..." 9 Thus, completion of such M\&A transaction may depend on whether the CEO receives private benefits, rather than the ultimate shareholder value increase.

Board members have fiduciary duties to examine all M\&A transactions proposed by senior management and other firms to ensure that the interests of shareholders are taken into account and protected. Prior studies show that independent directors' presence on the board significantly improves shareholder wealth in mergers and acquisitions. Byrd and Hickman (1992), for instance, examine the independent directors' influence on announcement-date abnormal returns and find that bidding companies with a majority of independent outsiders receive less-negative returns to shareholders than other firms. Nevertheless, the results of the 
study also illustrate that this trend ceases when independent directors hold more than $60 \%$ of the board seats. Chadam (2018) finds that board independence has a positive effect on the increase in bidders' cumulative abnormal returns over the deal announcement period. Cotter et al. (1997) provide evidence that the target company's shareholders enjoy higher gains over the tender offer period when the target's board of directors is independent of management.

Given that independent directors take their positions to improve corporate governance, it is reasonable to expect them to facilitate successful M\&A operations, in particular, if these directors have the necessary amount of knowledge and experience in this field. Specifically, the presence of directors with investment bank background increases the likelihood of higher announcement-date abnormal returns, since these directors contribute to better selection and evaluation of targets, reduce the dependence on external M\&A advisers and the cost of advisory services. ${ }^{10}$ Prior M\&A experience, among other things, allows independent directors not only to monitor through identifying potentially value-destroying decisions and proposals but also to advise managers. The benefits of such advising may be tremendous: the expertise and knowledge of directors can significantly help management in choosing a potential target, review and evaluation of M\&A proposals or during negotiations of the deal terms. In other words, directors' experience in mergers and acquisitions makes them an extremely valuable source of experience for companies. McDonald et al. (2008) provide evidence that outsiders' prior involvement in acquisition transactions have a positive effect on the acquisition performance of the company. Moreover, the authors emphasize that experienced outsiders bring the greatest benefits in cases when the upper management does not have a strong influence on the board. It is noteworthy that participation in acquisitions considerably increases the likelihood of these directors gaining new board positions (Harford and Schonlau, 2013), showing the value of such experiences in the labor market.

As it is known, the specialized functions of directors are manifested through their inclusion in the relevant board committees. However, at present M\&A committees are rarely included on the boards of directors. ${ }^{11}$ Moreover, unlike audit, nomination, and compensation committees $^{12}$, the creation of the committee consisting mostly or entirely of independent outsiders neither recommended nor required in most jurisdictions.

\section{CONCLUSION}

On the basis of the results of this research, it can be concluded that independent directors face a number of hurdles in the course of the execution of their core responsibilities. The present research focuses on three major situations involving agency conflicts between shareholders and managers: the dismissal and appointment of the CEO, the establishment of executive compensation, and M\&A transactions. In all if these situations, independent directors have to struggle with the intention of CEOs to entrench their position, gain and maintain control over the company and board of directors in particular, and extract as much as possible personal benefits at the expense of shareholders. The modern arrangement of public companies without concentrated ownership often contributes to strengthening the position of CEOs. If the CEO manages to establish control over the flow of information provided to the board, the presence of independent directors will not be of real benefit to shareholders. Shareholders face a real risk of being deprived of the opportunity to receive the necessary support and protection from board members. Thus, the expectation of mitigation of agency conflicts between shareholders and managers by independent directors needs to be underpinned by corporate governance reforms. 


\section{REFERENCES}

BAO, J., and EDMANS A., 2011, Do Investment Banks Matter for M\&A Returns?, The Review of Financial Studies, 24 (7), 2286-2315.

BEBCHUK, L.A. and FRIED J.M., 2004, Pay without Performance: The Unfulfilled Promise of Executive Compensation [online], http://www.law.harvard.edu/faculty/bebchuk/pdfs/performance-part1.pdf Accessed: 16 December 2019).

BYRD, J.W., and HICKMAN K.A., 1992, Do Outside Directors Monitor Managers? Evidence from Tender Offer Bids, Journal of Financial Economics, 32 (2), 195-221.

CHADAM, A.A., 2018, Does the Structure of the Board of Directors Improve M\&A Performance, International Journal of Synergy and Research, 7, 15-31.

COTTER, J.F., SHIVDASANI A., and ZENNER M., 1997, Do Independent Directors Enhance Target Shareholder Wealth during Tender Offers?, Journal of Financial Economics, 43 (2), 195-218.

DIKOLLI, S., MAYEW W.J., and NANDA D., 2014, CEO Tenure and the PerformanceTurnover Relation, Review of Accounting Studies, 19 (1), 281-327.

DSOUZA, D., 2019, Top 10 Highest Paid Executives for 2018, [online], https://www.investopedia.com/highest-paid-ceos-2019-4687532 (Date Accessed: 17 December 2019).

GRAHAM, J.R., KIM H., and LEARY M.T., 2017, CEO Power and Board Dynamics, Working Paper, Duke University, Cornell University, and Washington University.

GRAHAM, J.R., KIM H., and LEARY M.T., 2019, CEO-Board Dynamics, [online], https://papers.ssrn.com/sol3/papers.cfm?abstract_id=2938120 (Date Accessed: 5 December 2019).

HARFORD, J., and SCHONLAU R.J., 2013, Does the Director Labor Market Offer Ex Post Settling-Up for CEOs? The Case of Acquisitions, Journal of Financial Economics, 110 (3), 18-36.

HARTZELL, J., OFEK E., and YERMACK D., 2004, What's In It for Me? CEOs Whose Firms Are Acquired, Review of Financial Studies, 17 (1), 37-61.

HERMALIN, B.E., 2005, Trends in Corporate Governance, The Journal of Finance, 60 (5), 2351-2384.

HUANG, Q., JIANG F., LIE E., and YANG K., 2014, The Role of Investment Banker Directors in M\&A, Journal of Financial Economics, 112 (3), 269-286.

JENTER, D., and LEWELLEN K., 2015 CEO Preferences and Acquisitions, Journal of Finance, 70 (6), 2813-2852.

KRAAKMAN, R., et al., 2016, The Anatomy of Corporate Law. A comparative and Functional Approach: Third Edition, Oxford University Press, Oxford.

MAIN, B., O'REILLY C.A., and WADE J., 1995, The CEO, the Board of Directors, and Executive Compensation: Economic and Psychological Perspectives, Industrial and Corporate Change, 4 (2), 293-332.

MALMENDIER, U., and TATE G., 1990, Who Makes Acquisitions? CEO Overconfidence and the Market's Reaction, Journal of Financial Economics, 89 (1), 20-43. 
MASULIS, R.W., and GUO L., 2015, Board Structure and Monitoring: New Evidence from CEO Turnovers, The Review of Financial Studies, 28 (10), 2770-2811.

MCDONALD, M.L., WESTPHAL J.D., and GRAEBNER M.E., 2008, What Do They Know? The Effects of Outside Director Acquisition Experience on Firm Acquisition Performance, Strategic Management Journal, 29 (11), 1155-1177.

MOBBS, S., 2013, CEOs Under Fire. The Effects of Competition from Inside Directors on Forced CEO Turnover and CEO Compensation, Journal of Financial and Quantitative Analysis, 48 (3), 669-698.

MOELLER, S.B., SCHLINGEMANN F.P, and STULZ R.M., 2005, Wealth Destruction on a Massive Scale? A Study of Acquiring-Firm Returns in the Recent Merger Wave, The Journal of Finance, 60 (2), 757-782.

MURPHY, K.J., and ZÁBOJNÍK J., 2007, Managerial Capital and the Market for CEO, [online], https://papers.ssrn.com/sol3/papers.cfm?abstract_id=984376 (Date Accessed: 18 December 2019).

OECD, 2019, OECD Corporate Governance Factbook 2019, [online], http://www.oecd.org/corporate/Corporate-Governance-Factbook.pdf (Date Accessed: 21 December 2019).

SORKIN, A.R., 2002, Executive Pay: A Special Report; Those Sweet Trips to the Merger Mall, New York Times, [online], https://www.nytimes.com/2002/04/07/business/executivepay-a-special-report-those-sweet-trips-to-the-merger-mall.html (Date Accessed: 11 December 2019).

SPENCER STUART. 2019, 2018 United States Spencer Stuart Board Index, [online], https://www.spencerstuart.com/-/media/2019/july/ssbi_2018_new.pdf (Date Accessed: 7 December 2019).

STEIN, G., and PLAZA S., 2011, The Role of Independent Directors in CEO Supervision and Turnover, [online], https://papers.ssrn.com/sol3/papers.cfm?abstract_id=1782707 (Date Accessed: 6 December 2019).

SUN, J., and CAHAN S., 2009, The Effect of Compensation Committee Quality on the Association between CEO Cash Compensation and Accounting Performance, Corporate Governance: An International Review, 17 (2), 193-207.

TAYLOR, L. A., 2010, Why Are CEOs Rarely Fired? Evidence from Structural Estimation, Journal of Finance, 65 (6), 2051-2087.

WEISBACH, M., 1988, Outside Directors and CEO Turnover, Journal of Financial Economics, 20 (1), 431-460. 


\section{NOTES}

${ }^{1}$ OECD, "OECD Corporate Governance Factbook 2019, [online], http://www.oecd.org/corporate/CorporateGovernance-Factbook.pdf (Date Accessed: 21 December 2019), pages 116-117.

${ }^{2}$ Lucian A. Taylor, 2010, Why Are CEOs Rarely Fired? Evidence from structural estimation, Journal of Finance, 65 (6), page 2052.

3 John R. Graham, Hyunseob Kim, and Mark T. Leary, 2019, CEO-Board Dynamics, [online], https://papers.ssrn.com/sol3/papers.cfm?abstract_id=2938120 (Date Accessed: 5 December 2019).

${ }^{4}$ Shane Dikolli, William J. Mayew, and Dhananjay Nanda, 2014, CEO Tenure and the Performance-Turnover Relation, Review of Accounting Studies, 19 (1), page 294.

${ }^{5}$ Shawn Mobbs, 2013, CEOs Under Fire. The Effects of Competition from Inside Directors on Forced CEO Turnover and CEO Compensation, Journal of Financial and Quantitative Analysis, 48 (3), page 694.

6 Deborah Dsouza, 2019, Top 10 Highest Paid Executives for 2018, [online], https://www.investopedia.com/highest-paid-ceos-2019-4687532 (Date Accessed: 17 December, 2019).

${ }^{7}$ Guido Stein and Salvador Plaza, 2011, The Role of Independent Directors in CEO Supervision and Turnover, [online], https://papers.ssrn.com/sol3/papers.cfm?abstract_id=1782707 (Date Accessed: 6 December 2019).

${ }^{8}$ OECD, "OECD Corporate Governance Factbook 2019, [online], http://www.oecd.org/corporate/CorporateGovernance-Factbook.pdf (Date Accessed: 21 December 2019), page 121.

${ }^{9}$ Andrew R. Sorkin, 2002, Executive Pay: A Special Report; Those Sweet Trips to the Merger Mall, New York Times [online], https://www.nytimes.com/2002/04/07/business/executive-pay-a-special-report-those-sweettrips-to-the-merger-mall.html (Date Accessed: 11 December 2019).

${ }^{10}$ Qianqian Huang, Feng Jiang, Erik Lie, and Ke Yang, 2014, The Role of Investment Banker Directors in M\&A, Journal of Financial Economics, 112 (3), page 284.

${ }^{11}$ Spencer Stuart, 2019, 2018 United States Spencer Stuart Board Index [online], https://www.spencerstuart.com//media/2019/july/ssbi_2018_new.pdf (Date Accessed: 7 December 2019), page 25.

12 OECD, 2019, OECD Corporate Governance Factbook 2019, [online], http://www.oecd.org/corporate/Corporate-Governance-Factbook.pdf (Date Accessed: 21 December 2019), pages 116-117, 150-151. 
